\title{
Croton guatemalensis (Euphorbiaceae) phenology at the Zoque Tropical Forest Biological Corridor
}

\author{
Fenología de Croton guatemalensis \\ (Euphorbiaceae) en el Corredor Biológico Selva Zoque
}

\author{
Dulce María Pozo-Gómez ', Carolina Orantes-García², Tamara Mila Rioja-Paradela", Rubén Antonio Moreno-Moreno² \\ and Arturo Carrillo-Reyes ${ }^{1}$
}

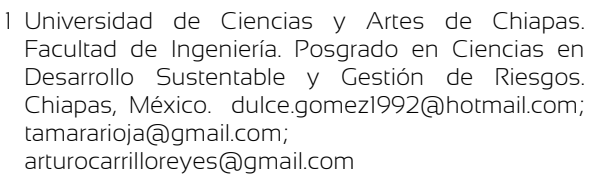

\author{
2 Universidad de Ciencias y Artes de Chiapas. Instituto \\ de Ciencias Biológicas. Chiapas, México \\ carolina.orantes@unicach.mx \\ ruben.moreno@unicach.mx. \\ * Corresponding author. tamararioja@gmail.com
}

\begin{abstract}
Croton guatemalensis is a threatened and multipurpose species in communities of southeastern Mexico and Central America. For the first time, its reproductive phenology and its relationship with environmental variables present in four different natural protected areas of the Zoque Tropical Forest Biological Corridor was determined. Throughout a year the flowering and fructification of the species was monitored, the local environmental variables were recorded and fruits and seeds were collected to determine, under a random design, the germination of the seeds and the growth of seedlings in the laboratory and in nursery respectively. In all cases, flowering was presented from July to April, while fructification occurred from March to September, coinciding with the months where the rains diminish considerably. In terms of seed germination, it presented a statistically significant difference between seeds from the four protected areas. The most contrasting results were presented between La Pera and Area Villa de Allende $(98 \% \pm 3.84 \%$ and $6 \% \pm$ $3.84 \%$ respectively). According to the generalized linear model, soil porosity was the only variable that influenced the germination of the species (the higher the porosity, the higher the percentage of final germination, $\mathrm{t}=2.237, \mathrm{P}=0.0503$ ). Because this is the first study on the ecophysiology of $C$. guatemalensis in southern Mexico, the importance of it becomes relevant when providing fundamental reproductive information for the generation of strategies for conservation, restoration and forest management of the species.
\end{abstract}

KEYWORDS: ecophysiology; flowering; fructification; germination; sexual reproduction; threatened species.

\section{RESUMEN}

Croton guatemalensis es una especie amenazada y multipropósito de comunidades del sureste de México y América Central. Por primera vez, se determinó su fenología reproductiva y su relación con las variables ambientales presentes en cuatro áreas naturales protegidas del Corredor Biológico Selva Zoque. A lo largo de un año, se monitoreó la floración y fructificación de la especie, se registraron las variables ambientales locales y se recolectaron frutos y semillas para determinar, bajo un diseño aleatorio, la germinación de las semillas y el crecimiento de las plántulas en el laboratorio y en el vivero respectivamente. En todos los casos, la floración se presentó de julio a abril, mientras que la fructificación ocurrió de marzo a septiembre, coincidiendo con los meses en que las lluvias disminuyen considerablemente. En términos de germinación de semillas, se presentó una diferencia estadísticamente significativa entre las semillas de las cuatro áreas naturales protegidas. Los resultados más contrastantes se presentaron entre La Pera y Área Villa de Allende (98\% \pm $3.84 \%$ y $6 \% \pm 3.84 \%$ respectivamente). Según el modelo lineal generalizado, la porosidad del suelo fue la única variable que influyó en la germinación de la especie (a mayor porosidad, mayor porcentaje de germinación final, $\mathrm{t}=2.237$, $\mathrm{P}=0.0503$ ). Debido a que este es el primer estudio sobre la ecofisiología de C. guatemalensis en el sur de México, el estudio se vuelve relevante al proporcionar información reproductiva fundamental para la generación de estrategias de conservación, restauración y manejo forestal de la especie.

PALABRAS CLAVE: ecofisiología; floración; fructificación; germinación; reproducción sexual; especie amenazada. 


\section{INTRODUCTION}

Currently, phenological studies have become more relevant due to the current process of global warming, since it has been observed that the biological processes of survival and reproductive success expressed as a function of phenology can improve the accuracy of future distribution prediction models of species under different climate change scenarios (Lorente et al., 2004). This happens mainly in those species that stand out for being multipurpose (Chuine \& Beaubien, 2001). Such is the case of Copalchí (Croton guatemalensis), a species whose distribution goes from southern Mexico to Panama, acclimated in South America and the Caribbean at altitudes of up to 1700 meters above sea level (Cardenas, 2006). In, Mexico this native species is considered to have special protection under the Mexican legislation (Secretaría de Medio Ambiente y Recursos Naturales [Semarnat], 2010); it is a species used by local communities as medicine, for use as live fences and poles, as firewood, for the extraction of wood, honey, fodder, or for construction and manufacturing of work tools (Pozo-Gómez, OrantesGarcía, Rioja-Paradela, Moreno-Moreno, \& FarreraSarmiento, 2019).

The Zoque Tropical Forest Corridor, where $C$. guatemalesis is distributed, is located between the states of Veracruz, Oaxaca and Chiapas, and is nowadays considered to be a center of biological (FlamencoSandoval, Martínez Ramos, \& Masera, 2007) (OrantesGarcía, Pérez-Farrera, Rioja-Paradela, Ramírez, \& Raymundo, 2013) and cultural diversity (Conservación Internacional [CI], 2004). In Chiapas, the Zoque Tropical Forest Corridor is made up of five different protected natural areas: The Ocote Tropical Forest Biosphere Reserve (REBISO), a Zone Subject to Ecological Conservation: La Pera, a Zone Subject to Ecological Conservation: Cerro Meyapac, the Villa Allende Tropical Forest Area (ZPFVVA) and the Sumidero Canyon National Park (PNCS) ( Arriaga et al., 2000); together they have an extension of more than 135000 hectares (Semarnat - Comisión Nacional de Áreas Naturales Protegidas [Conanp], 2001).
Notwithstanding the importance of $C$. guatemalensis in the Zoque Tropical Forest Biological Corridor, its current exploitation is carried out in wild populations without adequate forest management, and in addition there are no scientific studies on its ecophysiology that allow to generate suitable protocols for its reproduction, propagation and proper management (Pozo-Gómez et al., 2019).

\section{OBJECTIVES}

Therefore, the objective of this study was to determine, for the first time, the reproductive phenology of $C$. guatemalensis, from its flowering and fructification, to the germination of seeds and the growth of its seedlings, as well as the relationship that these biological processes have with some environmental variables present in different protected areas.

\section{MATERIALS AND METHODS}

\section{Study area}

The study was carried out in four natural protected areas (NPAs) of the Zoque Tropical Forest Biological Corridor, Chiapas, Mexico: a) The Ocote Tropical Forest Biosphere Reserve (REBISO), b) The Sumidero Canyon National Park (PNCS), c) the Zone Subject to Ecological Conservation, La Pera (ZSCELP) and d) The Villa de Allende Tropical Forest Area (ZPFVVA) (SemarnatConanp, 2001; Fig.1).

Phenological and environmental monitoring.- Throughout a year, monthly visits were carried out to each of the four NPAs for the monitoring of flowering and fructification, seed collection of $C$. guatemalensis and record the environmental variables (altitude, soil type, environmental temperature, monthly rainfall, and predominant vegetation in the monitoring site). The monitoring was conducted to accessible sites in an expanse of 1 hectare ensuring that significant populations of $C$. guatemalensis are found in each NPAs. For the correct identification of the species, samples were collected that were herborized according to Lot and Chiang (1990); the taxonomic identification was made through the review of specialized flora bibliography 
(Stevens, Ulloa, Pool, \& Olga, 2001) and through comparisons with the collections of the Ministry of Environment and Natural History Herbarium (CHIP: 44713), the Eizi Matuda Herbarium (HEM: DB-23664) and the National Herbarium of Mexico (IBUNAM: MEXUPVsn46367), as well as from the revision in the The Plant List [TPL] (2013) and Tropics database (Tropicos, 2017). The trees of $C$. guatemalensis were selected based on the probabilistic factor that a phenotype has sufficient genetic basis to show a favorable reaction to different environments; the selection was of a directional type, five specimens were selected per plot in each NPAs; according to inclusion criteria such as: the straightness of the stem, the natural pruning, the conformation of the crown and branches, free of pests and diseases (Centro Agronómico Tropical de Investigación y Enseñanza [Catie] 1995, Pola et al., 2003).

The date and duration of each phenotypic phase was recorded and the percentage of presence of each phenological character was evaluated through the $\mathrm{BBCH}$ general scale (Hess et al., 1997). This scale considers two digits, where the development cycle of the plant is divided into 10 recognizable and distinguishable phases called main growth stages numbered from zero to nine (first number); secondary growth stages (second number) were used to identify more accurately the growth progression of $C$. guatemalensis during the main growth stage.

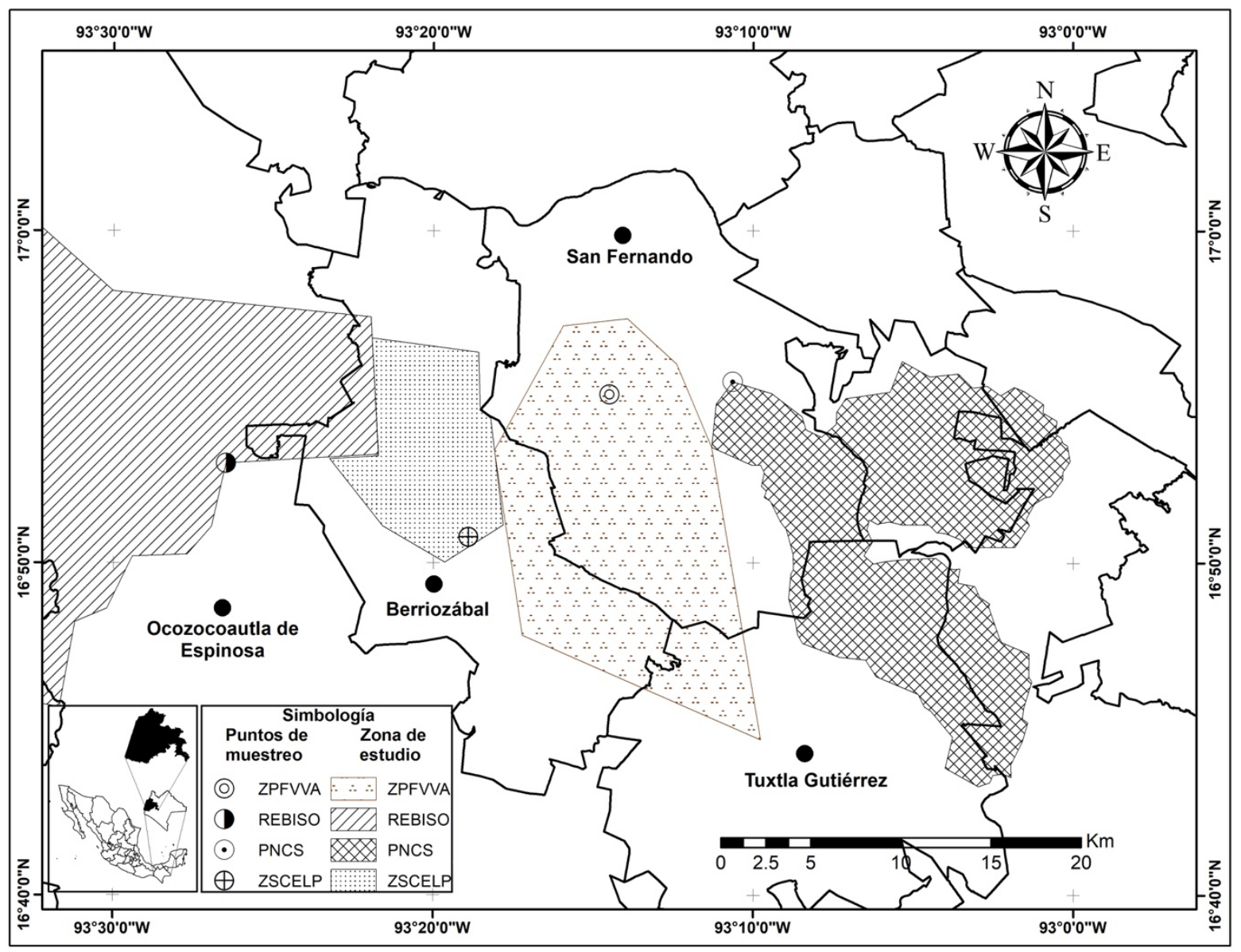

FIGURE 1. Study area at the Zoque Tropical Forest Biological Corridor, Chiapas, Mexico. Design: H. Gutiérrez-Santiag). 
The weather data of temperature and monthly pluvial precipitation were provided by the network of climatological stations of the National Water Commission and the National Institute of Research, Agriculture and Livestock of Chiapas. The altitude was obtained by a manual receiver of the global geo-positioning system (Garmin Leyend Etrex). Additionally, the predominant type of vegetal association was recorded according to the classification of Rzedowski (1994) to determine the presence of vegetable cover. Finally, a simple sampling of the soil was carried out to determine its quality through the collection of five samples per plot in each protected area, of one kilogram of soil each, with a recommended depth of $0 \mathrm{~cm}-20 \mathrm{~cm}$ and $20 \mathrm{~cm}-40 \mathrm{~cm}$. These depths are more practical as more uniform samples are obtained, quick to perform and cause less damage to the ground surface (Fournier, 1974). The samples were taken to the Plant Germplasm Bank Laboratory of the Institute of Biological Sciences at the University of Sciences and Arts of Chiapas (UNICACH) to determine their $\mathrm{pH}$, porosity, texture and organic matter through the procedure of Jaramillo (2002). Table 1 shows the environmental variables registered for each NPAs.

\section{Fruits and seed collection}

Once the fructification of the species was present, 100 fruits were collected from each tree monitored in each NPAs. The fruits were stored in labeled paper bags to be transferred to the Plant Germplasm Bank Laboratory of the Biological Sciences Institute at the University of Sciences and Arts of Chiapas (UNICACH). A total of 500 seeds were extracted from each NPA to determing the germination and growth percentage of each seedling in the nursery.

Seed germination. Under a completely randomized experimental design, the germination test was performed, with three repetitions of 30 seeds of homogeneous measurements that were taken from the total lot collected for each NPAs (30 seeds $\times 3$ repetitions $\times 4$ NPAs). After two days of harvesting, the 360 seeds were sown at a depth of two $\mathrm{cm}$ with the micropyle down in 12 Koper block ${ }^{\circledR}$ type unicel trays for forest species $(60 \mathrm{~cm} \times 35 \mathrm{~cm} \times 12$ $\mathrm{cm}$ ), with substrate collected from each NPAs. The experiment was conducted in a nursery with shaded mesh (70\% shade), maintained temperature of $26{ }^{\circ} \mathrm{C}$ and humidity of $78 \%$; irrigation and data collection were taken once every 3 days. The seeds were considered germinated when they presented epicotyl emergence on the substrate (> $5 \mathrm{~mm}$ ) (Hartmann \& Kester, 2001). Each tray was considered as an experimental unit, with time as an independent variable and as response variables the percentage average of final germination (GP), the average time of germination (T), the germination speed (GS), the germination index (GI) and the speed coefficient (GC) (González-Zertuche \& Orozco-Segovia, 1996). The observation and annotation corresponding to the growth and development of the seedlings, type of germination, primary leaves, length and thickness of the stem, number of leaves and length of the root for the identification of the species in its early stage (seedling) were made (LópezRíos, 2005). The diameter of the stem and height of the seedling were determined with an Ohaus trademark $0 \mathrm{~mm}$ - $150 \mathrm{~mm}$ caliper digital calibrator with precision of 0.1 $\mathrm{mm}$. The leaves were only counted according to the number of shoots. The data were taken at $(15,20,30,45$ and 60) days, and irrigation was given once every 3 days (López-Ríos, 2005).

\section{Statistical analysis}

To determine the possible relationship between the environmental variables present in each protected area and flowering and fructification of C. guatemalensis, a simple correlation analysis was carried out (Ríos García, 2015). For the production of fruits, it was verified that the data had a normal distribution (mesokurtic) with standardized kurtosis values and standardized bias within the range -2 to +2 according to the normality test (Shapiro test). Having no normal distribution, the non-parametric Kruskal-Wallis test was carried out to compare the production of fruits from the four PNAs (Duplancic et al., 2015). In terms of 
germination, descriptive statistics were first carried out to obtain the mean and standard deviation of the germination in each NPAs. Subsequently, it was verified that the data obtained had a normal distribution with values of standardized kurtosis and standardized bias within the -2 to +2 range, according to the normality test (Shapiro test); as it did not have a normal distribution, the non-parametric Kruskal-Wallis test was carried out to compare the germination among the seeds from the four NPAs, and subsequently, the Mann-Whitney $U$ test was performed, using the Bonferroni fit for the identification of possible groups (Duplancic et al., 2015). To determine which environmental variables influenced the final germination result, a generalized linear model (MLG) was carried out (R Core Team, 2018); where the variables of temperature and precipitation were excluded from this analysis since these variables were the same throughout the experimental design of germination because it was carried out in the same nursery for all the seeds. Finally, the observation and annotation corresponding to the growth and development of the seedlings, germination type, primary leaves, length and thickness of the stem, number of leaves and length of the root for the identification of the species in its early stage (seedling) were carried out (López-Ríos 2005). All statistical analyzes were performed using the R 3.24 software and the statistical data package Past ${ }^{\circledR}$ and Statgraphics $\AA$ (Hammer et al. 2001; R Core Team, 2018).

\section{RESULTS}

\section{Flowering and Fructification}

The phenological events of flowering and fructification of C. guatemalensis occurred only once a year in each NPAs; flowering started in the month of July ( $25 \%$ of individuals $\mathrm{n}=5 \pm 4.82)$ and extended until April (25\% of individuals), with December and January being the months with the highest percentage of individuals with flowers $(100 \%$ of individuals $\mathrm{n}=20 \pm 8.4$ ). Fructification began in March ( $25 \%$ of individuals), extending until September ( $25 \%$ of individuals); the months of May and June presented the highest amount of fruits $(75 \% \mathrm{n}=15 \pm 3.33$ and $100 \%$ of the individuals $n=20 \pm 3.42$, respectively (Table 2, Fig. 2). According to the Kruskal-Wallis analysis, there were significant differences in fruit production between the four NPAs (K=12.38, $P=<0.006)$. ZSCELP $(28248 \pm 2578.7)$ was the area with the largest fruits, followed by PNCS (35460 \pm 1670.6$)$, REBISO (37313 \pm 2060.2$)$ and finally ZPFVVA (43103 \pm 5730.7$)$. In all the NPAs, a moderately strong relationship was observed between flowering and temperature, flowering and rainfall, fructification and temperature, and fructification and rainfall (Table 2).

TABLE 1. Characteristics of the NPAs within the Zoque Tropical Forest Biological Corridor, Chiapas, Mexico.

\begin{tabular}{|c|c|c|c|c|c|c|c|c|c|}
\hline \multirow{2}{*}{ NPAs } & \multirow{2}{*}{$\begin{array}{c}\text { Altitude } \\
\text { (asl) }\end{array}$} & \multicolumn{2}{|c|}{$M T\left({ }^{\circ} \mathrm{C}\right)$} & \multirow{2}{*}{$\begin{array}{l}\text { MPP } \\
(\mathrm{mm})\end{array}$} & \multicolumn{4}{|c|}{ Soil } & \multirow[t]{2}{*}{$P V$} \\
\hline & & Min. & Max. & & $p H$ & $O M(\%)$ & $P(\%)$ & $T$ & \\
\hline ZSCELP & 1010 & 27.8 & 17.5 & 61.2 & 6.8 & 4.9 & 63 & $C$ & HPTF \\
\hline REBISO & 953 & 26.9 & 16.3 & 86.4 & 7.7 & 4.4 & 55 & $C L$ & MPTF \\
\hline PNCS & 1200 & 28.1 & 14.0 & 68.7 & 7.4 & 3.8 & 48 & $C$ & MPTF \\
\hline ZPFVVA & 780 & 27.4 & 14.0 & 68.7 & 5.4 & 2.7 & 36 & SLC & SV \\
\hline
\end{tabular}

Monthly temperature = MT, Monthly Pluvial Precipitation = MPP, Organic Matter = OM, Porosity = P, Texture = T, Clay = C, Clay Loam = CL, Sandy Loam-Clay = SLC, 
TABLE 2. Correlation analysis between flowering-temperature, flowering-precipitation, fructification-temperature and fructificationprecipitation in the four NPAs of the Zoque Tropical Forest Biological Corridor.

\begin{tabular}{|c|c|c|c|c|}
\hline \multicolumn{5}{|c|}{ Flowering - Temperature } \\
\hline NPAs & Correlation coefficient & $R^{2}$ & $F$ & Pvalue \\
\hline ZSCELP & 0.77 & $59.9 \%$ & 7.48 & 0.0410 \\
\hline REBISO & 0.88 & $78.04 \%$ & 17.77 & 0.0084 \\
\hline PNCS & 0.92 & $84.80 \%$ & 27.92 & 0.0032 \\
\hline ZPFVVA & 0.81 & $65.9 \%$ & 9.67 & 0.0266 \\
\hline \multicolumn{5}{|c|}{ Flowering-Pluvial Precipitation } \\
\hline NPAs & Correlation coefficient & $R^{2}$ & $F$ & Pvalue \\
\hline ZSCELP & -0.78 & 62.11 & 8.20 & 0.0353 \\
\hline REBISO & -0.87 & $75.7 \%$ & 15.58 & 0.0109 \\
\hline PNCS & -0.91 & $84.2 \%$ & 26.74 & 0.0036 \\
\hline ZPFVVA & -0.96 & $93.3 \%$ & 69.70 & 0.0004 \\
\hline \multicolumn{5}{|c|}{ Fructification - Temperature } \\
\hline NPAs & Correlation coefficient & $R^{2}$ & $F$ & Pvalue \\
\hline ZSCELP & 0.94 & $88.7 \%$ & 39.27 & 0.0015 \\
\hline REBISO & 0.89 & $79.37 \%$ & 19.24 & 0.0071 \\
\hline PNCS & 0.90 & $82.41 \%$ & 23.44 & 0.0047 \\
\hline ZPFVVA & 0.81 & $67.0 \%$ & 10.19 & 0.0242 \\
\hline \multicolumn{5}{|c|}{ Fructification - Precipitation } \\
\hline NPAs & Correlation coefficient & $R^{2}$ & $F$ & Pvalue \\
\hline ZSCELP & -0.76 & $57.8 \%$ & 6.85 & 0.0472 \\
\hline REBISO & -0.74 & $56.0 \%$ & 6.39 & 0.0527 \\
\hline PNCS & -0.84 & $71.1 \%$ & 12.35 & 0.0170 \\
\hline ZPFVVA & -0.96 & $92.5 \%$ & 62.11 & 0.0005 \\
\hline
\end{tabular}

\section{Germination}

Table 3 shows the means and standard deviations of $C$. guatemalensis germination in each NPAs. According to the Kruskal-Wallis analysis, there were statistically significant differences in the germination percentage (GP) $(K=9.31$, $P=<0.025)$, time $(\mathrm{T})(\mathrm{K}=8.56, P=<0.036)$, germination index (GI) $(\mathrm{K}=9.49 ; P=<0.023)$, germination speed (GS) $(\mathrm{K}=10.38, P=<0.016)$ and germination coefficient $(\mathrm{GC})$ $(\mathrm{K}=8.56 ; P=<0.036)$ of $C$. guatemalensis seeds from the four NPAs. Both ZSCELP and REBISO had the highest percentage of final germination $(98 \% \pm 3.84 \%$ and $88 \% \pm$
$11.70 \%$, respectively), followed by PNCS $(72 \% \pm 8.38 \%)$ with moderate germination and ZPFVVA (6\% 3.84; Table 3) the lowest.

Through the generalized linear model (GLM) is was observed that of all the environmental variables evaluated for the final germination percentage, soil porosity was the only significant variable $(\mathrm{t}=2.237, P=0.0503)$, with a positive relationship with the germination; the greater the porosity of the soil, the greater the percentage of final germination that was obtained (Table 4). 


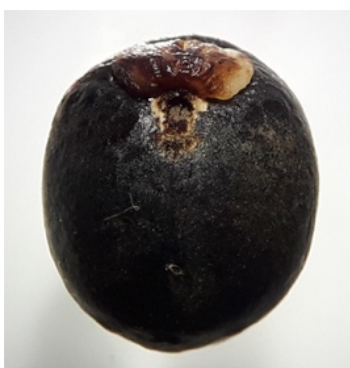

A
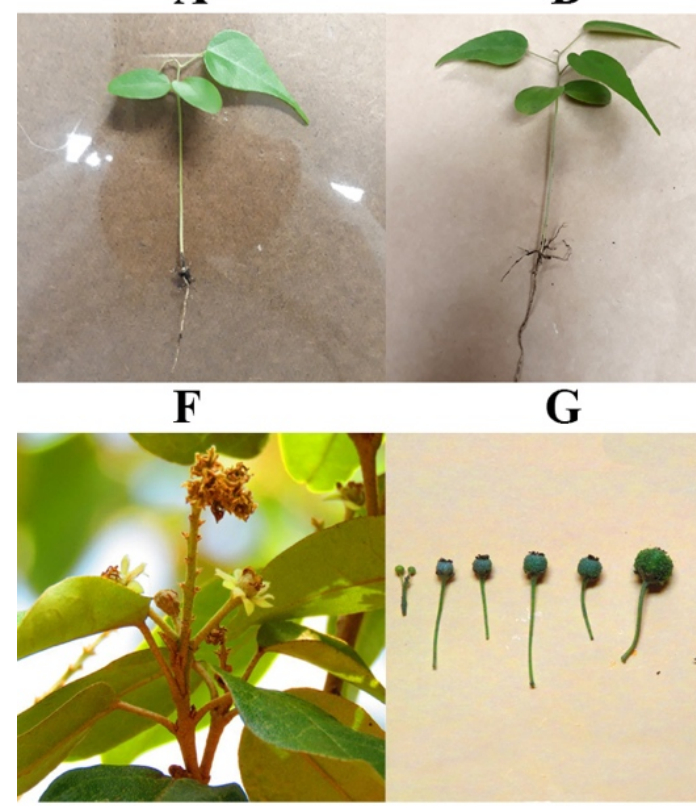

K

G

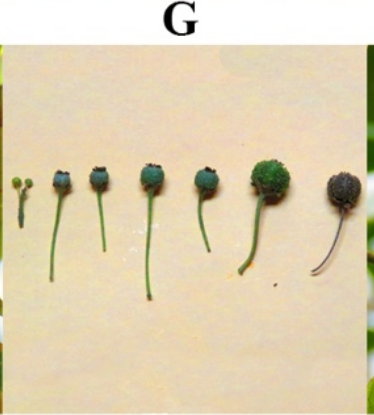

$\mathbf{L}$

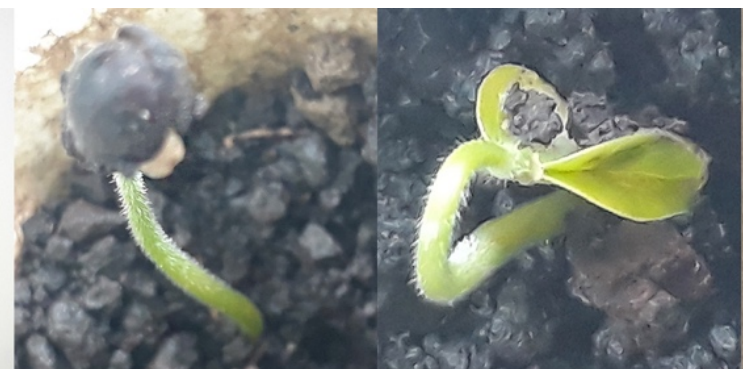

C

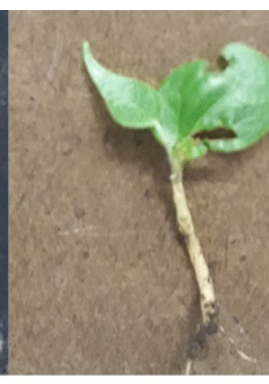

D

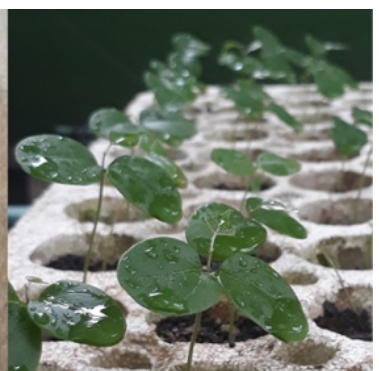

E

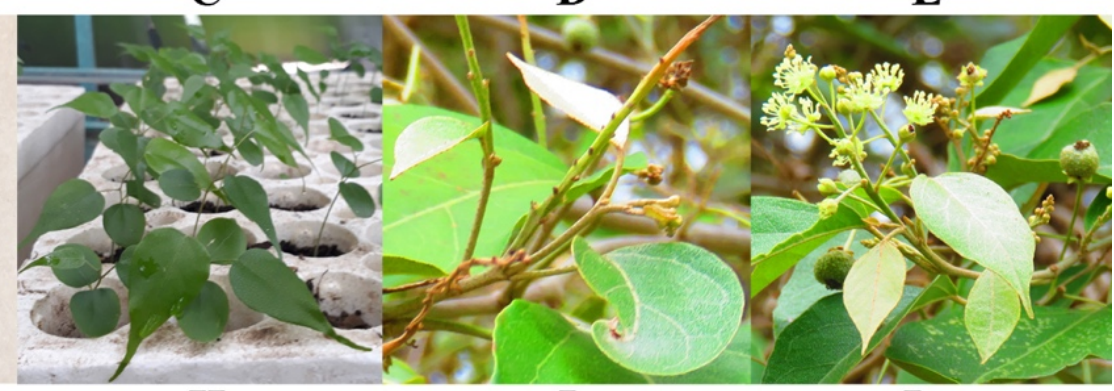

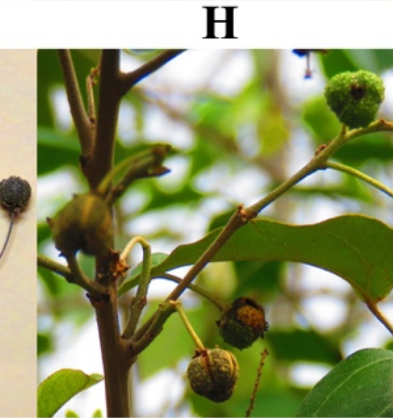

M
I

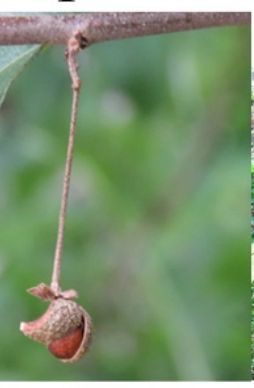

$\mathbf{N}$

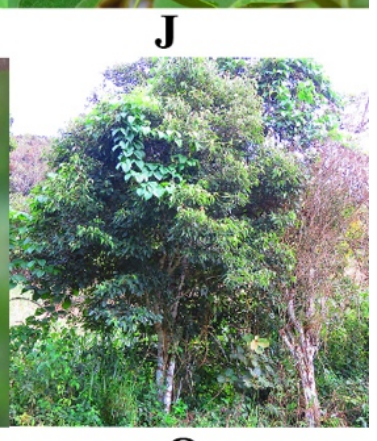

O

FIGURE 2. Main and secondary growth stages of $C$. guatemalensis.

A: Viable seed, BC: Germination type epigeous, DE: False leaves (cotyledon), FGH: appearance of 2 to 3 leaves, I: formation of flower spikes, JK: Flowering and beginning of fructification, LMN: Complete fructification and ripening, O: End of growth, perennifolia plant.

TABLE 3. Comparison of means and standard deviations of germination in the seeds of C. guatemalensis in the four NPAs.

\begin{tabular}{llllll}
\hline & $G P$ & $T$ & $G I$ & $G S$ & $G C$ \\
\hline ZSCELP & $98 \pm 3.84^{\mathrm{d}}$ & $12 \pm 0^{\mathrm{a}}$ & $11.73 \pm 0.46^{\mathrm{b}}$ & $4.586 \pm 0.15^{\mathrm{c}}$ & $8.33 \pm 0^{\mathrm{a}}$ \\
REBISO & $88 \pm 11.70^{c \mathrm{~d}}$ & $21 \pm 3^{\mathrm{bc}}$ & $18.66 \pm 5.11^{\mathrm{b}}$ & $3.93 \pm 0.47^{\mathrm{c}}$ & $4.828 \pm 0.69^{\mathrm{a}}$ \\
PNCS & $72 \pm 8.38^{\mathrm{b}}$ & $23 \pm 1.73^{\mathrm{c}}$ & $16.533 \pm 1.22^{\mathrm{b}}$ & $1.928 \pm 0.35^{\mathrm{b}}$ & $4.365 \pm 0.34^{\mathrm{a}}$ \\
ZPFVVA & $6 \pm 3.84^{\mathrm{a}}$ & $13 \pm 6.24^{\mathrm{a}}$ & $0.833 \pm 0.85^{\mathrm{a}}$ & $0.137 \pm 0.06^{\mathrm{a}}$ & $9.629 \pm 6.11^{\mathrm{a}}$ \\
\hline
\end{tabular}

Final germination percentage (GP), average germination time (T), germination index (GI), germination speed (GS) and germination coefficient (GC). The groups are given by the U Mann-Whitney test.

\pm Standard deviation. Uneven letters show statistical differences. The variables of temperature and precipitation were excluded from this analysis since these variables were the same throughout the experimental design of germination because it was carried out in the same nursery. 
TABLE 4. Generalized Linear Model Analysis for the soil variables evaluated in the final germination process.

\begin{tabular}{ccc}
\hline Variables & t value & Pvalue \\
\hline Soil weight & -0.837 & 0.4302 \\
Soil pH & 1.244 & 0.2535 \\
Soil organic matter & -0.325 & 0.7546 \\
Soil porosity & 2.237 & 0.0503 \\
Soil humidity & -0.329 & 0.7517 \\
Soil health & -0.626 & 0.5511 \\
Soil texture & -0.111 & 0.9148
\end{tabular}

\section{Growth and development of seedlings}

The germination of the seeds was of the epigeal type, the cotyledons emerged from the soil due to a considerable growth of the hypocotyl (portion between the radicle and the insertion point of the cotyledons). From day three to five the seed coat, cotyledons and epicotyl of the seedling emerged from the ground, thus forming the primary root. After five days, the plumule (cotyledonary leaves) originated, from which the adventitious roots developed. From 20 days to 30 days the first leaves appeared (true leaves) and at 35 days the process of lignification of the stem, increase in thickness and length began (Fig. 2, Table 5).

\section{DISCUSSION}

C. guatemalensis is an annual species whose reproductive phenology (flowering and fructification) is intimately related to the variables of environmental temperature and monthly rainfall $(65 \mathrm{~mm})$, with the highest percentage of flowering and fructification occurring in the season of least rainfall and with the presence of high temperatures $\left(28^{\circ} \mathrm{C}\right)$. This coincides with reports of Wright and Schaik (1994), who claim that arboreal species in similar sites have a period of greater flowering at the time of greatest drought, phase with the highest irradiation. On the other hand, Morellato et al. (2000) in a study conducted with tree species in the tropical forests of the southeastern Brazil, found that the period of flowering and fruit production occurs shortly before the period of humidity, relating it to the importance of the length of the day and temperature. This relationship found is very important as it warns of the indispensability of carrying out studies on the effect of climate change on the future potential distribution of $C$. guatemalensis; the effect that both environmental variables have on the flowering and fructification of this plant is very clear, and therefore it is likely that if the temperature and rainfall change this could change the distribution area of the species. Yepes \& Buckeridge (2011) point out that climate change is influencing the distribution of tropical mountain plants, which move to higher surfaces. Also, Arias-Aguilar et al. (2016) claim that phenological cycles in plants are being significantly affected; a predicted change is the predominance of "weeds" or opportunistic species at the expense of the scarcity of species with more ecological requirements, which caused altitude migrations of species, projecting local extinctions in the short term. 
TABLE 5. Main and secondary growth stages of C. guatemalensis, according to the general scale Biologische Bundesanstalt and Chemische Industrie (BBCH; Hess et al., 1997).

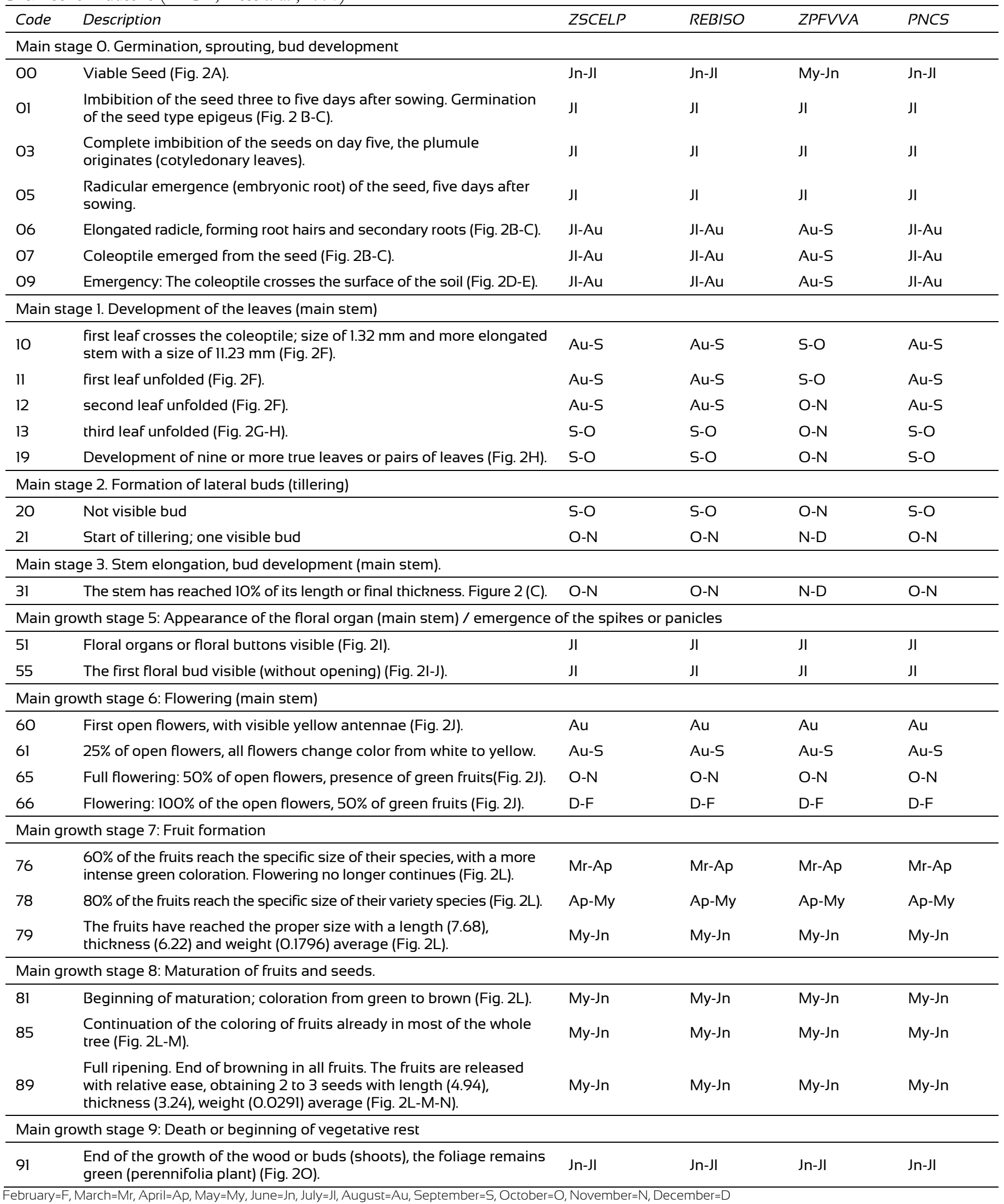


Regarding the germination of C. guatemalensis, a clear relation between the percentage of final germination and the degree of porosity of the soil is observed, since the greater the porosity, a higher percentage of germination of the species was registered. While genetic conditions are important factors, environmental factors affect the characteristics and quality of the seeds of different species (Meyer et al., 1989, Keller and Kollmann, 1999). In C. guatemalensis the highest percentage of germination was registered in seeds from the ZSCELP area, with soil of greater porosity and also rich in organic matter, with surrounding vegetation throughout the year of high evergreen forest, which can allow a better development of the seeds of this species, in contrast to the ZPFVVA area, with less porous soil and also poorer in organic matter, with presence of secondary vegetation, which favored that the seeds of this ANP had a low percentage of germination.

The environmental variable determining the percentage of germination was the porosity of the soil, which according to Handreck and Black (1994), affects the gaseous exchange capacity of the medium; a poorly porous soil or with small pores, as well as low clay content, hinders this exchange and causes water to easily form puddles, causes water to form puddles that can decrease oxygen in the air spaces and reduce the organic matter in the soil. This caused damages the the colloidal structure, produces poor drainage, increases erosion and damages microbial life, essential elements that seeds require for germination.

In addition to this, the physicochemical characteristics of soil are essential to determine the growth and development of seedlings (Castellanos, 2000); for example, C. guatemalensis presented an epigeous type germination and the seedlings presented appearance of the first leaves from 25 days to 30 days and thickening of the stem at 35 days after sowing, which allows to obtain a high percentage of survival in suitable soil conditions, a result that was reflected in the ZSCELP area, where the physicochemical characteristics adequate for the good development of seedlings were obtained, as compared to ZPFVVA (Arriaga, Cervantes, Vargas, \& Guzmán, 1994). The relationship found between soil type, germination and establishment of seedlings is relevant to establish the effect of land use change by anthropogenic activities on the distribution of C. guatemalensis, since it is likely that poor and weakly porous soils produced by agricultural activities such as the establishment of monocultures, use of agrochemicals to improve the effectiveness of crops in the short term, require immediate attention as this activity has a greater number of irreversible impacts on soil degradation (Handreck and Black 1994, Ayala-Sierra and Valdez-Aguilar 2008, Menchaca and Alvarado 2011); therefore, from the results of this investigation, it is recommend to carry out studies on the effect of land use change on the distribution of this species, and develop management strategies that allow an adequate management of the current agricultural and/or livestock activities that exist in the Zoque Tropical Forest Biological Corridor, to maintain soil conservation soil conservation with the purpose of cushioning the degradation of ecosystems and protecting species such as C. guatemalensis that require porous and well-preserved soils.

\section{CONCLUSIONS}

The accomplishment of basic studies that allow to obtain information on the reproductive phenology (flowering, fructification), and the germination of different vegetal species represents a fundamental step for its suitable handling and conservation. With the results presented in this study, basic information is generated to contribute to the conservation and propagation of C. guatemalensis, a species not only cataloged as threatened by the Mexican legislation (NOM-059-SEMARNAT-2010), but also with local use by the communities settled along the Zoque Tropical Forest Biological Corridor and throughout other Latin American countries.

\section{ACKNOWLEDGEMENTS}

The authors thank the National Council of Science and Technology (CONACYT) for the scholarship granted for the completion of the master's degree in Sustainable Development and Risk Management of the University of Sciences and Arts of Chiapas. 


\section{REFERENCES}

Arias-Aguilar, D., Acosta-Vargas, L. G., Rodríguez-González, A., \& Quesada-Quirós, M. (2016). Efecto del cambio climático sobre el patrón de distribución de las especies de plantas en el Parque Nacional Volcán Irazú (PNVI) basado en simulaciones a mediano y largo plazo. Instituto Tecnológico de Costa Rica., 68 pp.

Arriaga, C. L., Espinoza-Rodríguez, J. M., Aguilar-Zúñiga, C., MartínezRomero, E., Gómez-Mendoza, L., \& Loza, E. (2000). Regiones Terrestres Prioritarias de México. Retrieved from http://www.conabio.gob.mx/conocimiento/regionalizacion/do ctos/terrestres.html

Arriaga, V. M., Cervantes, Vargas, A. M., \& Guzmán. (1994). Manual de reforestación con especies nativas: colecta y preservación de semillas, propagación y manejo de plantas (1a edición). México: SEDESOL: Instituto Nacional de Ecología: UNAM, Facultad de Ciencias.

Ayala-Sierra, A., \& Valdez-Aguilar, L. A. (2008). El polvo de coco como sustrato alternativo para la obtención de plantas ornamentales para trasplante. Revista Chapingo. Serie Horticultura, 14(2), 161-167.

Cardenas, M. L. I. (2006). Validación farmacológica de la actividad analgésica de las infusiones de la corteza de Spondias purpurea L. (Jocote), hojas de Chyranthodendron pentadactylon (Manita) y Croton guatemalensis (Copalchi). Universidad de San Carlos de Guatemala Facultad de Ciencias Químicas y Farmacia, Guatemala. Retrieved from http://biblioteca.usac.edu.gt/tesis/06/06_2484.pdf

Castellanos, J. Z. (2000). Manual de Interpretación de Análisis de Suelos, Aguas (2a ed.). Guanajuato, México: Ed. Intagri.

Centro Agronómico Tropical de Investigación y Enseñanza [Catie] (1995). Mejoramiento forestal y conservación de recursos genéticos forestales. Turrialba, Costa Rica: Manual Técnico.

Chuine, I. \& Beaubien, E. G. (2001). Phenology is a major determinant of tree species range. Ecology Letters, 4(5), 500-510. doi: 10.1046/j.1461-0248.2001.00261.x

Conservación Internacional [CI] (2004). Northern region of The Mesoamerica biodiversity botspot. Conservation International, Mexico and Central American Program (p. 58). Retrieved from http://www.conservation.org/global/mexico/Pages/partnerlan ding.aspx

Duplancic, M. A., Martínez Carretero, E., Cavagnaro, B., Herrera Moratta, M., Romero, N., \& Laura, A. (2015). Factores que inciden en la germinación de Araucaria araucana (Araucariaceae) del bosque xérico. Revista de La Facultad de Ciencias Agrarias. Universidad Nacional de Cuyo, 47(2), 71-82.

Flamenco-Sandoval, A., Martínez Ramos, M., \& Masera, O. R. (2007). Assessing implications of land-use and land-cover change dynamics for conservation of a highly diverse tropical rain forest.
Biological Conservation, 138(1), 131-145. doi: 10.1016/j.biocon.2007.04.022

Fournier, F. (1974). Conservación de suelos (Vol. 3). Madrid: Ediciones Mundi-Prensa.

González-Zertuche, L. \& Orozco-Segovia, A. (1996). Methods far seed germination data analysis. An example: Manfreda brachystachya. Botanical Sciences, 58, 15-30. doi: 10.17129/botsci.1484

Hammer, O., Harper, D. A. T., \& Ryan, P. D. (2001). PAST: PAleontological STatistics software package for education and data analysis. Palaentologia Electronica, 4, 1-9.

Handreck, K. \& Black, N. D. (1994). Growing media for ornamental plants and turf (Rev. ed). Retrieved from https://trove.nla.gov.au/work/9552415

Hartmann, H. T. \& Kester, D. E. (2005). Propagación de Plantas: Principios y Prácticas (3 ed). CECSA.

Hess, M., Barralis, G., Bleiholder, H., Buhr, L., Eggers, Th., Hack, H., \& Stauss, R. (1997). Use of the extended BBCH scale-general for the descriptions of the growth stages of mono; and dicotyledonous weed species. Weed Research, 37(6), 433-441. doi: 10.1046/j.1365-3180.1997.d01-70.x

Jaramillo, J. D. F. (2002). Introducción a la Ciencia de Suelo (Vol. 1). Universidad Nacional de Colombia.

Keller, M. \& Kollmann, J. (1999). Effects of seed provenance on germination of herbs for agricultural compensation sites. Agriculture, Ecosystems \& Environment, 72(1), 87-99. doi: 10.1016/S0167-8809(98)00167-4

López-Ríos, G. F. (2005). Ecofisiología de árboles. México, D.F., México: Universidad Autónoma Chapingo.

Lorente, I., Gamo, D., Gómez, J. I., Santos, R., Flores, L., Camacho, A., ..., \& Navarro, J. (2004). Los efectos biológicos del cambio climático. Revista Ecosistemas, 13(1), 103-110.

Lot, A. \& Chiang, F. (1990). Administración y manejo de colecciones, técnicas de recolección y preparación de ejemplares botánicos (1st ed.). D.F., México: Consejo Nacional de la Flora de México.

Menchaca D., M. S. \& Alvarado M., E. L. (2011). Efectos antropogénicos provocados por los usuarios del agua en la microcuenca del Río Pixquiac. Revista Mexicana de Ciencias Agrícolas, 2(SPE1), 85-96.

Meyer, S. E., McArthur, E. D., \& Jorgensen, G. L. (1989). Variation in Germination Response to Temperature in Rubber Rabbitbrush (Chrysothamnus nauseosus: Asteraceae) and Its Ecological Implications. American Journal of Botany, 76(7), 981-991. doi: 10.1002/j.1537-2197.1989.tb15078.x 
Morellato, L. P. C., Talora, D. C., Takahasi, A., Bencke, C. C., Romera, E. C., \& Zipparro, V. B. (2000). Phenology of Atlantic Rain Forest Trees: A Comparative Study. BIOTROPICA 32(4b), 811-823.

Orantes-García, C., Pérez-Farrera, M. Á., Rioja-Paradela, T. M., Ramírez, G.-, \& Raymundo, E. (2013). Viabilidad y germinación de semillas de tres especies arbóreas nativas de la selva tropical, Chiapas, México. Polibotánica, 36, 117-127. doi: https://doi.org/10.18387/polibotanica.36.13

Pola, C. N. de P., Musálem, M. Á., \& Alcalá, J. O. (2003). Estudio de algunas características de conos y semillas de Abies religiosa. Agrociencia, 37, 521-531

Pozo-Gómez, D. M., Orantes-García, C., Rioja-Paradela, T. M., Moreno-Moreno, R. A., \& Farrera-Sarmiento, O. (2019). Diferencias en morfometría y germinación de semillas de Croton guatemalensis (Euphorbiaceae), procedentes de poblaciones silvestres de la Selva Zoque, Chiapas, México. Acta Botanica Mexicana, 126. doi: 10.21829/abm126.2019.1384

R Core Team. (2018). R: A Language and Environment for Statistical Computing. R Foundation for Statistical Computing.Vienna, Austria. Retrieved February 8, 2019, from https://www.rproject.org/

Ríos García, C. A. (2015). Estudio Fenológico del árbol de Totoposte (Licania arborea Seem: Chrysobalanaceae) (Tesis de Licenciatura). Universidad de Ciencias y Artes de Chiapas, Tuxtla Gutiérrez, Chiapas.

Rzedowski, J. (1994). Vegetación de México (6a ed). México D.F.: Limusa.

Secretaría de Medio Ambiente y Recursos Naturales [Semarnat] (2010). NORMA Oficial Mexicana NOM-059-SEMARNAT-2010. Protección ambiental-Especies nativas de México de flora y fauna silvestres-Categorías de riesgo y especificaciones para su inclusión, exclusión o cambio-Lista de especies en riesgo. Secretaría del Medio Ambiente y Recursos Naturales. Diario Oficial de la Federación. Retrieved February 8, 2019, from http:/ /dof.gob.mx/nota_detalle.php?codigo $=5173091 \&$ fecha $=$ $30 / 12 / 2010$
Secretaría de Medio Ambiente y Recursos Naturales [Semarnat] Comisión Nacional de Áreas Naturales Protegidas [Conanp] (2001). Programa de manejo de la Reserva de la Biosfera Selva El Ocote. México (Ed. 1). Retrieved from https://simec.conanp.gob.mx/TTH/Ocote/Ocote_TTH_2000 _2009.pdf

Stevens, W. D., Ulloa, C. U., Pool, A. M., \& Olga, M. (2001). Flora de Nicaragua (Vol. 85). St. Louis, Missouri: Missouri Botanical Garden Press.

The Plant List [TPL] (2013). The Plant List. Version 1.1. Retrieved May 5, 2017, from http://www.theplantlist.org/

Tropicos (2017). Tropicos.org. Missouri Botanical Garden. Retrieved from http://www.tropicos.org/

Wright, S. J. \& Schaik, C. P. van. (1994). Light and the phenology of tropical trees. The American Naturalist, 143, 192-199

Yepes, A. \& Buckeridge, M. S. (2011). Respuestas De Las Plantas Ante Los Factores Ambientales Del Cambio Climático Global (revisión). Colombia Forestal, 14, 213-232.

Received: 26 May 2019

Accepted: 12 August 2019

Published: 23 April 2020

This paper must be cited as:

Pozo-Gómez. D. M., Orantes-García, C., Rioja-Paradela, T. M., Moreno-Moreno, R. A., Carrillo-Reyes, A. (2020). Croton guatemalensis (Euphorbiaceae) phenology at the Zoque Tropical Forest Biological Corridor. Madera y Bosques, 26(2), e2621969. doi: 10.21829/myb.2020.2621969

Madera y Bosques by Instituto de Ecología, A.C. is distributed under a Creative Commons Licence Attribution-NonCommercial-ShareAlike $\quad 4.0$ Internacional. 